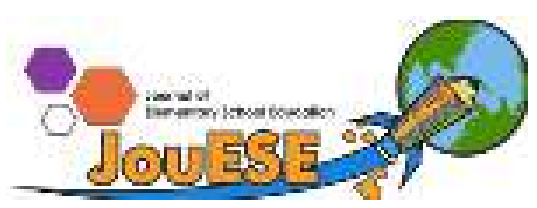

\title{
PENGARUH \\ MODEL PEMBELAJARAN INQUIRI TERBIMBING TERHADAP HASIL BELAJAR MAHASISWA
}

\author{
Yesi Budiarti ${ }^{1)}$, Hera Mutiah ${ }^{2)}$ \\ ${ }^{1)}$ FKIP, Universitas Muhammadiyah Pringsewu Lampung \\ ${ }^{2)}$ FKIP, Universitas Muhammadiyah Pringsewu Lampung \\ yesi.budiarti@yahoo.com
}

\begin{abstract}
Lecturers have a role to determine effective learning methods to support students in gaining valuable experiences. The research aim is to find out the effect of using guided inquiry learning methods on student learning outcomes. This research is an ex post facto experiment. The samples were 91 students of PGSD. The result is $t$ observed is 1.67 at the 5\% level of significant indicating that tob $>$ ttab, which means that the use of guided inquiry learning methods has a significant influence on student learning outcomes in the PGSD study program of Muhammadiyah University Pringsewu 2019/2020.
\end{abstract}

Keywords: inquiry, sttudent learning outcomes

\section{PENDAHULUAN}

Proses pembelajaran yang efektif dan menyenangkan dapat menimbulkan kepuasan bagi pihak-pihak yang terlibat dalam kegiatan proses pembelajaran. Kepuasan bagi mahasiswa dapat memahami seluruh pelajaran yang telah disampaikan dengan cara yang menyenangkan atau tidak membosankan sedangkan kepuasan bagi pihak dosen yaitu dapat mencapai tujuan pembelajaran yang diharapkan. Proses pembelajaran dapat berjalan dengan efektif dapat ditentukan oleh suatu metode pembelajaran. Metode mempunyai andil yang cukup besar dalam kegiatan belajar mengajar. Tujuan pembelajaran akan dapat dicapai dengan mengunakan metode yang tepat, sesuai dengan standar keberhasilan yang ada dalam suatu tujuan.

Berdasarkan hasil observasi dan hasil evaluasi kuis kesatu pada perkuliahan Pengembangan Pembelajaran IPS SD, hasil belajar mahasiswa program studi pendidikan guru sekolah dasar Universitas Muhammadiyah Pringsewu masih memiliki rata-rata rendah sehingga belum sesuai dengan yang diharapkan.

Metode inquiri terbimbing merupakan suatu teknik atau cara yang digunakan oleh guru dan dosen untuk mengajar. Metode inquiri mempunyai 
tujuan umum menolong dan mengembangkan disiplin intelektual dan keterampilan. Metode ini dilakukan dengan memberikan pertanyaan yang harus dipecahkan atau dikerjakan oleh mahasiswa. Pengolahan data dilakukan dengan melihat buku-buku yang dimiliki dan mendiskusikannya dengan teman sehingga jawaban yang diharapkan atas dasar rasa ingin tahu mereka dapat diperoleh.

Hasil belajar adalah "sesuatu yang diperoleh siswa setelah melakukan kegiatan belajar"( Savitri, 2013). Hasil belajar bisa dilihat setelah peserta didik melakukan kegiatan belajar. Karena belajar merupakan proses dalam diri peserta didik yang berinteraksi dengan lingkungan untuk mendapatkan perubahan dalm prilakunya. sedangkan menurut Purwanto (2016:34) menyatakan bahwa "hasil belajar merupakan perubahan prilaku siswa akibat belajar". Belajar adalah proses untuk membuat perubahan dalam diri peserta didik dengan cara berinteraksi dengan lingkungan untuk mendapatkan perubahan dalam aspek kognitif, efektif dan psikomotorik. Setelah melakukan kegiatan belajar guru dapat melihat perubahan prilaku peserta didik. Hal ini juga diperkuat oleh pendapat Karwono dan Mularsih (2012:13) yang menyatakan bahwa ciri hasil belajar adalah perubahan seseorang dikatakan sudah belajar apabila prilakunya menunjukkan perubahan, dari awalnya tidak mampu menjadi mampu, dari tidak trampil menjadi trampil. Faktor-faktor yang Mempengaruhi Hasil Belajar yang di kemukakan oleh Hatjanto (2006) adalah "faktor internal dan faktor eksternal". Proses belajar dan pembelajaran dipengaruhi oleh faktor internal dan faktor eksternal, faktor internal meliputi faktor fisiologis dan faktor psikis, dan faktor eksternal berupa segala sesuatu yang berada diluar diri peserta didik yang meliputi lingkungan keluarga, lingkungan sekolah, dan lingkungan masyarakat. Jadi untuk mengetahui hasil belajar peserta didik dipengaruhi oleh faktor internal dan faktor eksternal. Hal ini diperkuat oleh pendapat Karwono dan Mularsih (2012:46) menyatakan bahwa faktor-faktor yang mempengaruhi hasil belajar antara lain 1) Faktor internal individu, diklasifikasikan menjadi dua, yaitu Faktor fisiologis. Faktor fiiologis meliputi keadaan jasmani, serta faktor psikologis yang meliputi: intelegensi, emosi, bakat, motivasi, perhatian, dan daya nalar; 2) Faktor eksternal individu, antara lain a) faktor lingkungan sekolah, berupa cara memberi pelajaran dan bahan-bahan bacaan, media dan sebagainya; b) faktor lingkungan keluarga, 
meliputi perhatian orang tua, sarana dan prasarana belajar di rumah dan sebagainya; serta c) faktor lingkungan masyarakat yaitu tempat tinggal peserta didik.

Pembelajaran dengan mengunakan model inquiri mempunyai tujuan tersendiri, menurut Sanjaya (2008:197) yang menyatakan bahwa tujuan pembelajaran inquiri adalah mengembangkan kemampuan berpikir secara sistematis, logis dan kritis atau mengembangkan kemampuan intelektual sebagai bagian dari proses mental. Menurut pendapat Trianto (2010:166) menyatakan "pembelajaran inquiri berarti suatu rangkaian kegiatan belajar yang melibatkan secara maksimal seluruh kemampuan siswa untuk mencari dan menyelidiki secara sistematis, kritis, logis, analitis sehingga mereka dapat merumuskan sendiri penemuannya dengan penuh percaya diri”. Sanjaya (2008:196) menekankan bahwa "model pembelajaran inquiri rangkaian kegiatan pembelajaran yang menekankan pada proses berpikir secara kritis dan analitis untuk mencari dan menemukan sendiri jawaban dari suatu masalah yang dipertanyakan".

Mudjiono dan Dimyati, (2009:173), yang berpendapat bahwa metode inquriy merupakan pengajaran yang mengharuskan siswa mengolah pesan sehingga memperoleh pengetahuan, keterampilan dan nilai-nilai”. Metode ini juga memungkinkan proses belajar yang tenang dan menyenangkan karena pembelajaran dilakukan secara alamiah sehingga siswa dapat mempraktekan secara langsung apa-apa yang dipelajarinya.

Menurut pendapat Hanafiah (2012:79) kelebihan metode inquiri adalah

a. Membantu peserta didik utuk mengembangkan, kesiapan serta penguasaan keterampilan dalam proses kognitif

b. Peserta didik memperoleh pengetahuan secara individual sehingga dapat dimengerti dan mengendap dalam pikirannya

c. Dapat membangkitkan motivasi dan gairah belajar peserta didik untuk belajar lebih giat lagi

d. Memberikan peluang untuk berkembang dan maju sesuai dengan kemampuan dan minat masing-masing 


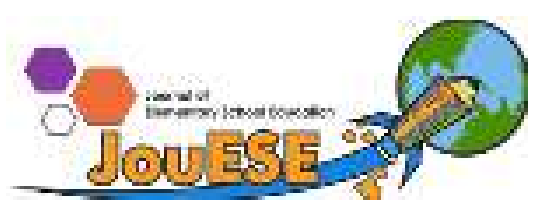

e. Memperkuat dan menambah kepercayaan pada diri sendiri dengan proses menemukan sendiri karena pembelajaran berpusat pada peserta didik dengan peran guru yang sangat terbatas.

Ada beberapa langkah yang harus Sanjaya (2008:201) juga berpendapat secara umum proses pembelajaran dengan menggunakan metode inquiri dapat mengikuti langkah-langkah sebagai berikut:
a. Orientasi
b. Merumuskan masalah
c. Mengajukan hipotesis
d. Mengumpulkan data
e. Menguji hipotesis
f. Merumuskan kesimpulan

\section{METODE PENELITIAN}

Penelitian yang dilakukan adalah eksperimen, dengan jenis eksperimen ex post facto. Metode inquiri terbimbing merupakan variabel bebas dan hasil belajar merupakan variabel terikat. Penelitian ini menggunakan desain posttestonly control design menggunakan 2 kelompok, yaitu kelas eksperimen dan kelas kontrol. Kedua kelompok memperoleh materi yang sama dan kemampuan kelas sejajar. Kelas eksperimen adalah kelas yang mendapat pembelajaran menggunakan metode inquiri terbimbing saat pembelajaran.

\section{HASIL DAN PEMBAHASAN}

Berdasarkan hasil analisis data penelitian yang diperoleh melalui pengujian hipotesis yang telah diuraikan sebelumnya ternyata hipotesis yang penulis ajukan yaitu terdapat pengaruh penggunaan metode inquiri terbimbing terhadap hasil belajar mahasiswa program studi PGSD universitas Muhammadiyah Pringsewu tahun 2019/2020. Dari perhitungan terlihat pada taraf $5 \%$ adalah 1,67 menunjukkan bahwa $t_{\text {hit }}>t_{\text {daf }}$ dengan demikian kesimpulan yang diperoleh adalah tolak $\mathrm{H}_{0}$ dan terima $\mathrm{H}_{\mathrm{I}}$ yang berarti bahwa pembelajarannya menggunakan metode inquiri mempunyai pengaruh terhadap hasil belajar mahasiswa program studi PGSD universitas Muhammadiyah Pringsewu tahun 2019/2020. 


\begin{tabular}{|c|c|c|c|c|c|}
\hline No & Kelas & Nilai & $\begin{array}{c}\text { Jumlah } \\
\text { Siswa }\end{array}$ & Kategori & Presentase \\
\hline 1 & Eksperimen & $\geq 70$ & 46 & 38 & $82,6 \%$ \\
\hline 2 & Kontrol & $<70$ & 45 & 28 & $62,2 \%$ \\
\hline \multicolumn{2}{r|}{ Jumlah } & $\mathbf{6 6}$ & $\mathbf{9 1}$ & $\mathbf{1 0 0} \%$ \\
\hline
\end{tabular}

Tabel 1 Pengaruh Metode Inquiri terhadap Hasil Belajar Mahasiswa

Berdasarkan proses kegiatan pembelajaran di kelas pada saat pelaksanaan penelitian terlihat bahwa terdapat hasil belajar yang berbeda antara mahasiswa kelas eksperimen yang pembelajarannya menggunakan metode inquiri terbimbing dan kelas kontrol pembelajarannya menggunakan metode diskusi variatif. Hal tersebut dapat dilihat pada proses pembelajaran berlangsung.

Hal seperti itu juga diungkapkan oleh Sanjaya (2008:208) bahwa "strategi pembelajaran inkuiri terbimbing merupakan strategi pembelajaran yang menekankan kepada pengembangan aspek kognitif, afektif dan psikomotor secara seimbang, sehingga pembelajaran melalui strategi ini dianggap lebih bermakna”. Pembelajaran yang menggunakan strategi inkuiri terbimbing akan membuat suasana belajar lebih menarik sehingga membangkitkan rasa ingin tahu mahasiswa dalam pembelajaran yang dapat meningkatkan hasil belajarnya. Strategi inkuiri terbimbing merupakan strategi merangsang mahasiswa bersifat seperti ilmuwan yang belajar menemukan jawabanya sendiri dari suatu masalah yang diberikan sesuai prosedur inquiri, sehingga akan lebih tertarik dan termotivasi. Apabila mahasiswa semakin tertarik pada suatu materi maka kemampuan berpikir pun juga akan lebih baik. Sehingga hasil belajar mahasiswa siswa dapat meningkat lebih baik.

Berdasarkan uraian di atas, mahasiswa diharapkan dapat membangun pemahamannya sendiri tentang realita sosial dengan cara merekontruksi sendiri "makna" melalui pemahaman pribadinya. Mereka dilibatkan dalam melakukan eksplorasi situasi baru, dalam mempertimbangkan dan merespon permasalahan secara kritis dan dalam menyelesaikan permasalahannya sacara realistis.

Dari kegiatan pembelajaran model inquiri terbimbing, mahasiswa dapat menyelesaikan kesulitan-kesulitan yang diberikan tersebut. Hal ini bisa diketahui dari proses penyelesaian permasalahannya. Setelah diadakan tes, mahasiswa yang pembelajarannya menggunakan model inquiri terbimbing sebagian besar nilainya 


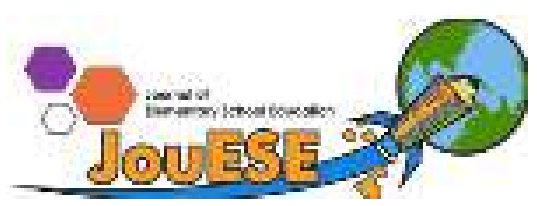

mencapai angka di atas 70 dari 45 yang tidak mencapai KKM hanya 8 mahasiswa. Ternyata model inquiri terbimbing ini dapat meningkatkan hasil belajar karena mahasiswa lebih aktif dan terlihat secara langsung dalam usaha memperoleh pemahaman teori-teori.

\section{SIMPULAN}

Berdasarkan analisis data dan pengujian hipotesis, terdapat pengaruh penggunaan metode inquiri terbimbing terhadap hasil belajar mahasiswa program studi PGSD Universitas Muhammadiyah Pringsewu. Dari kegiatan pembelajaran model inquiri terbimbing, mahasiswa dapat menyelesaikan kesulitan-kesulitan yang diberikan tersebut. Hal ini bisa diketahui dari proses penyelesaian permasalahannya. Setelah diadakan tes, mahasiswa yang pembelajarannya menggunakan model inquiri terbimbing sebagian besar nilainya mencapai angka di atas 70 dari 45 yang tidak mencapai KKM hanya 8 mahasiswa. Ternyata model inquiri terbimbing ini dapat meningkatkan hasil belajar karena mahasiswa lebih aktif dan terlihat secara langsung dalam usaha memperoleh pemahaman teoriteori.

\section{DAFTAR PUSTAKA}

Dimyati dan Mudjiono. 2009. Belajar dan Pembelajaran. Jakarta: Rineka Cipta

Hanafiah, Nanang dan Cucu Suhana. 2012. Konsep Strategi Pembelajaran. Bandung: PT Refika Aditama

Harjanto. 2006. Perencanaan Pengajaran. Jakarta: Rineka Cipta

Karwono dan Heni Mularsih. 2012. Belajar dan Pembelajaran serta Pemanfaatan Sumber Belajar. Jakarta:PT Raja Grafindo Persada.

Purwanto. (2016). Evaluasi Hasil Belajar. Yogyakarta: Pustaka Pelajar

Sanjaya, Wina. 2008. Strategi Pembelajaran. Jakarta: Kencana

Trianto. 2010. Model-Model Pembelajaran Inovatif Berorientasi Konstruktivistik. Jakarta: Prestasi Pustaka 